\title{
The Plant-Dependent Life Cycle of Thecaphora thlaspeos: A Smut Fungus Adapted to Brassicaceae
}

\author{
Lamprinos Frantzeskakis, ${ }^{1}$ Kaitlyn J. Courville, ${ }^{1}$ Lesley Plücker, ${ }^{1}$ Ronny Kellner, ${ }^{2}$ Julia Kruse, ${ }^{3}$ \\ Andreas Brachmann, ${ }^{4}$ Michael Feldbrügge, ${ }^{1}$ and Vera Göhre ${ }^{1}$ \\ ${ }^{1}$ Institute for Microbiology, Cluster of Excellence in Plant Sciences, Heinrich-Heine University, Building 26.12.01, \\ Universitätsstr.1, 40205 Düsseldorf, Germany; ${ }^{2}$ Max-Planck Institute for Plant Breeding Research, Carl-von-Linné-Weg 10, \\ 50829 Cologne, Germany; ${ }^{3}$ Institute of Ecology, Evolution and Diversity, Faculty of Biological Sciences, Goethe University \\ Frankfurt am Main, Max-von-Laue-Str. 9, D-60438 Frankfurt am Main, Germany; and ${ }^{4}$ Ludwig-Maximilians-Universität \\ München, Faculty of Biology, Genetics, Großhaderner Straße 2-4, 82152 Planegg-Martinsried, Germany
}

Accepted 30 January 2017.

\begin{abstract}
Smut fungi are globally distributed plant pathogens that infect agriculturally important crop plants such as maize or potato. To date, molecular studies on plant responses to smut fungi are challenging due to the genetic complexity of their host plants. Therefore, we set out to investigate the known smut fungus of Brassicaceae hosts, Thecaphora thlaspeos. T. thlaspeos infects different Brassicaceae plant species throughout Europe, including the perennial model plant Arabis alpina. In contrast to characterized smut fungi, mature and dry $T$. thlaspeos teliospores germinated only in the presence of a plant signal. An infectious filament emerges from the teliospore, which can proliferate as haploid filamentous cultures. Haploid filaments from opposite mating types mate, similar to sporidia of the model smut fungus Ustilago maydis. Consistently, the $a$ and $b$ mating locus genes are conserved. Infectious filaments can penetrate roots and aerial tissues of host plants, causing systemic colonization along the vasculature. Notably, we could show that $T$. thlaspeos also infects Arabidopsis thaliana. Exploiting the genetic resources of A. thaliana and Arabis alpina will allow us to characterize plant responses to smut infection in a comparative manner and, thereby, characterize factors for endophytic growth as well as smut fungi virulence in dicot plants.
\end{abstract}

Fungal diseases are a major threat to modern agriculture (Fisher et al. 2012). Despite vast efforts undertaken to control disease, e.g., chemical treatments, resistance breeding, and improved agricultural practices, significant economic losses still befall every year (Oerke 2006). The smut fungi are a group of biotrophic plant pathogens that infect important crops such as barley, wheat, maize, and potato and can cause substantial yield losses and grain quality reduction (Kronstad 1996). Typical symptoms of smut-infected crop plants are formation of

\section{Frantzeskakis and K. J. Courville contributed equally to this work.}

Corresponding author: V. Göhre; Telephone: +49 21181 11529; E-mail: vera.goehre@hhu.de

*The $\boldsymbol{e}$-Xtra logo stands for "electronic extra" and indicates that six supplementary figures, three supplementary tables, and two supplementary movies are published online.

(ㄷ) 2017 The American Phytopathological Society melanized, dark-pigmented teliospores in inflorescences, seeds, or leaves, leaf tissue rupture, and stunted growth (Vánky 2012).

Many smut fungi can grow as nonpathogenic, saprotrophic sporidia until they find a mating partner with which they fuse to form a filamentous, pathogenic dikaryon (Brefort et al. 2009). This dimorphic life cycle is best characterized in Ustilago maydis, the causal agent of corn smut (Banuett 1992; Vollmeister et al. 2012). The switch from saprophytic growth to pathogenic development starts with mating (Bölker et al. 1992), and filament formation is controlled by a heterodimerizing transcription factor (Feldbrügge et al. 2004; Kämper et al. 1995). In these filaments, plant signals from the leaf surface induce appressorium formation and penetration of the plant tissue (Lanver et al. 2014; Mendoza-Mendoza et al. 2009). Upon successful penetration, fungal hyphae rapidly proliferate in infected tissue and induce tumor formation for the deposition of diploid teliospores. In corn, these can be released within four weeks after initial infection (Pataky and Chandler 2003) to start a new infection cycle (Feldbrügge et al. 2004). In contrast to the rapid life cycle of Ustilago maydis, which allows several infections per season, the head smut fungus Sporisorium reilianum infects maize via the roots and grows slowly, like an endophyte, through the plant until sporogenesis occurs in the floral meristem (Martinez et al. 2002). Similarly, several small grain smuts, such as U. hordei infecting barley, follow the plant life cycle. Their teliospores overwinter inside seeds or in the soil and infect seedlings during early development in the season (Hu et al. 2002).

Although there is detailed molecular understanding of morphological changes and infection strategies in smut fungi (Vollmeister et al. 2012), the investigation of molecular mechanisms underlying resistance remains difficult, due to the genetic complexity of polyploid host grasses. Despite extensive breeding and mapping efforts that led to the identification of resistance genes in maize, barley, and wheat (Baumgarten et al. 2007; Grewal et al. 2008; Knox et al. 2014), the molecular mechanisms of resistance remain largely elusive. By contrast, a wealth of information on the plant immune system and plant responses to fungal infection comes from the model plant Arabidopsis thaliana (Asai and Shirasu 2015; Cook et al. 2015), which has led to translational approaches for plant protection (Brewer and Hammond-Kosack 2015; Lacombe et al. 2010). Therefore, it would be highly useful to combine the sophisticated molecular tools and resources of smut fungi and A. thaliana.

T. thlaspeos is a smut fungus that adapted to infect Brassicaceae hosts. It is described in at least 15 host species, including 
Arabis hirsuta as well as the perennial model plants Arabis alpina and Arabidopsis lyrata and also Cardamine spp. (Vánky et al. 2008), a plant genus that is used to study the evolution of plant development (Hay et al. 2014). In infected host plants, T. thlaspeos produces single spores in the siliques, replacing seeds with spores. Previously, rDNA sequencing provided molecular data for clear identification of T. thlaspeos in Arabis hirsuta (Vánky et al. 2008). Despite morphological descriptions of teliospores and their germination, the infection process of T. thlaspeos in Brassicaceae is still unknown. Here, we describe the plant-dependent life cycle of $T$. thlaspeos and demonstrate that this smut is able to systemically infect $A$. thaliana.

\section{RESULTS}

\section{Collection and identification}

of the Brassicaceae smut fungus T. thlaspeos.

In the last five years, we identified T. thlaspeos in Germany, Slovenia, and Greece (Table 1) on three different host species, i.e., Arabis hirsuta, Arabis ciliata, and Arabis sagittata. Repeated collections at four sites in Germany during four consecutive years indicate that these populations are stable. T. thlaspeos-infected plants showed no macroscopic symptoms such as growth defects, distorted leaf growth, abnormal root, shoot, or flower development (Fig. 1A). Infected plants were identified by the presence of spores in place of developing seeds within the siliques (Fig. 1B and C). Further sequencing of large subunit ribosomal DNA from genomic DNA of these spores confirmed $T$. thlaspeos as the causal agent of plant disease (Table 1; Supplementary Fig. S1B). Spores inside siliques differentiated from young hyaline, white-colored spores into a pale brown spore mass (Fig. 1B and C). Characteristic warts were visible on mature teliospores (Fig. 1D). In contrast to previous observations (Vánky 1999), we observed infected plants with siliques that contained both spores and viable seeds. Cogermination of seeds and spores from sporulating siliques resulted in infected plants (Supplementary Fig. S2). This suggests vertical transmission as one propagation route for T. thlaspeos.

Overall, the Brassicaceae smut T. thlaspeos is dispersed throughout Europe (Vánky 1994) and populations are stable over years. Teliospores that are typical for smut fungi specifically develop in siliques of the host plant.

\section{Teliospores germinate in response} to a dormancy-breaking plant signal.

Teliospores of various smut fungi germinate readily in minimal media such as $0.2 \%$ malt agar or water agar without any requirements for specific temperature or humidity (Ingold 1992). Surprisingly, mature T. thlaspeos teliospores remained dormant in standard nutrient-rich and nutrient-poor media commonly used for fungi (Andrade et al. 2004; Holliday 1961; Ingold 1988; Kent et al. 2008; Murashige and Skoog 1962).
However, in the presence of germinating host seeds, teliospores readily germinated at rates up to $76 \%$ (Fig. 2A; Supplementary Movie S1). This suggests that, in contrast to all characterized smut fungi, a plant signal might be essential to break dormancy and initiate growth in T. thlaspeos teliospores. The plant signal is not host-specific, as spores also germinated in the presence of nonhost plants such as Arabis montbretiana and Brassica napus (Brassicaceae), Cleome hasseleriana (Cleomaceae), as well as Oxalis stricta (Oxalidaceae). By contrast, dormancy was not broken in the presence of Calystegia sepium (Convolvulaceae) (Supplementary Table S1). Furthermore, autoclaved exudates of plant leaves still induced germination, suggesting that the signal is heat-stable.

\section{Teliospores germinate with infectious filaments.}

After germination, the germ tubes proliferated without development of yeast-like sporidia as described for $T$. saponariae or T. schwarzmaniana (Vánky and Lutz 2007; Vasighzadeh et al. 2014). In contrast to infectious filaments formed by $U$. maydis, T. thlaspeos filaments were not arrested in cell cycle
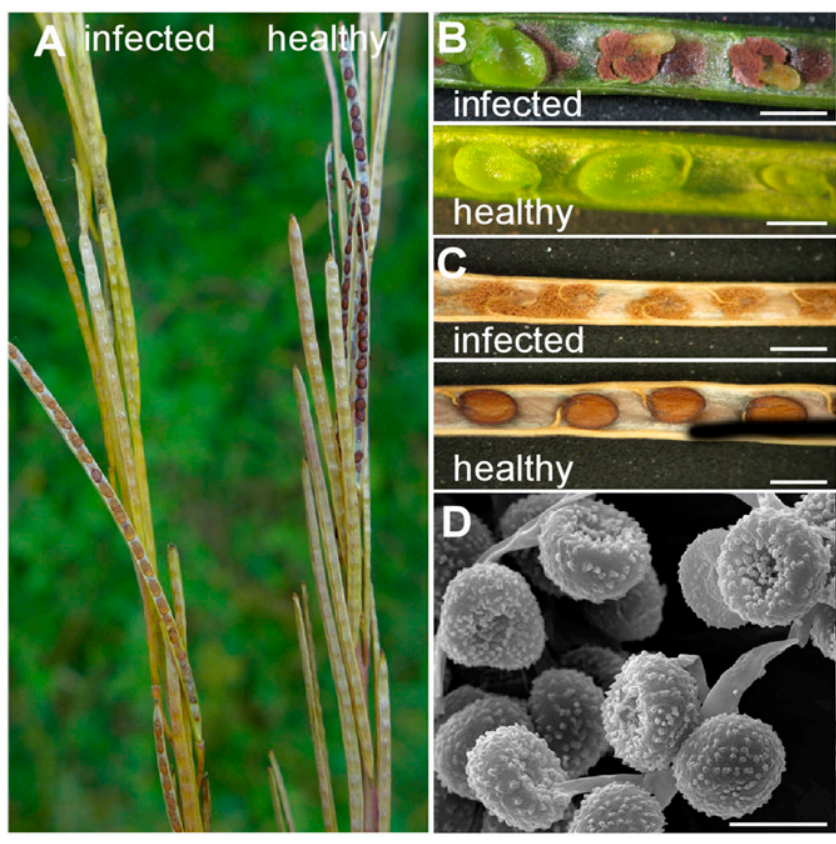

Fig. 1. Symptoms of Thecaphora thlaspeos infection on Arabis hirsuta and Arabis ciliata. A, Infected and healthy Arabis hirsuta plants collected in Germany appear macroscopically identical. Scale bar: $2 \mathrm{~cm}$. B, In siliques of these infected plants, spores cover developing seeds. Scale bar: $1 \mathrm{~mm}$. C, Similarly, infected Arabis ciliata siliques found in Slovenia in 2013 contained fungal teliospores. Scale bar: $1 \mathrm{~mm}$. D, Scanning electron microscopy of $T$. thlaspeos spores shows the typical dense wart-like surface decoration. Scale bar, $10 \mu \mathrm{m}$.

Table 1. Isolates of Thecaphora thlaspeos ${ }^{\mathrm{a}}$

\begin{tabular}{|c|c|c|c|}
\hline Host & Location & Identifier & Citation \\
\hline Arabis hirsuta & Romania & LSU (EF647754), ITS (KJ579178.1) & Vánky and Lutz 2007 \\
\hline Arabis hirsuta & Germany, Ronheim & LSU (KX686748)/ITS & This study \\
\hline Arabis hirsuta & Germany, Bad Berneck & LSU (KX686747) & This study \\
\hline Arabis hirsuta & Germany, Eselsburg & LSU (KX686746) & This study \\
\hline Arabis hirsuta & Germany, Hohe Leite & LSU (KX686745) & This study \\
\hline Arabis ciliata $^{\mathbf{b}}$ & Slovenia & Spores in siliques & This study \\
\hline Arabis sagittata ${ }^{\mathbf{b}}$ & Greece & Spores in siliques & This study \\
\hline
\end{tabular}

\footnotetext{
${ }^{a}$ Spores were collected from infected plants from 2011 to 2015 in Germany. T. thlaspeos occurred in the described host Arabis hirsuta. Sequencing of the large subunit rDNA (LSU) confirmed the macroscopic classification as T. thlaspeos. ITS = intergenic transcribed spacer.
}

${ }^{\mathrm{b}}$ Two additional hosts, Arabis ciliata and Arabis sagittata, were observed in Slovenia and Greece. 
but continued growth in the absence of the host plant. The growing germ tubes inserted empty sections at the basal pole of every cell, attached to the plant surface, and directly infected the cocultured seedlings (Fig. 2A). During this proliferation, we detected neither clamp cells nor coiled structures, as described in the potato smut T. solani (Andrade et al. 2004), nor intratetrad mating between compatible compartments of the germ tubes, as reported for some Ustilaginaceae species (Ingold 1988, 1989). Whereas most T. thlaspeos germ tubes initially contained two nuclei (Fig. 2B), they seem to distribute into daughter filaments during further cell divisions (Fig. 2B). Prolonged incubation of germinated spores for 4 to 6 weeks
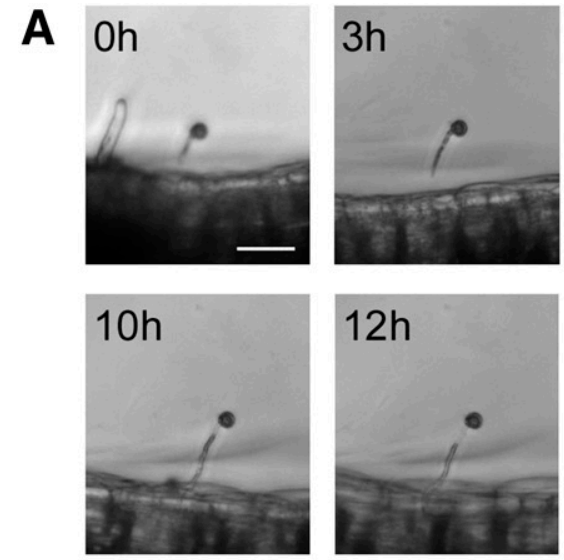

B
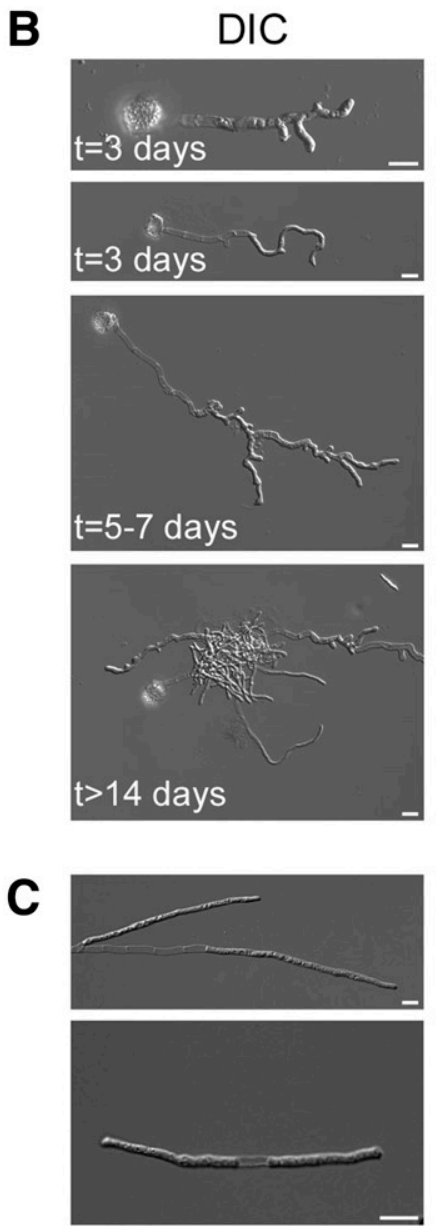
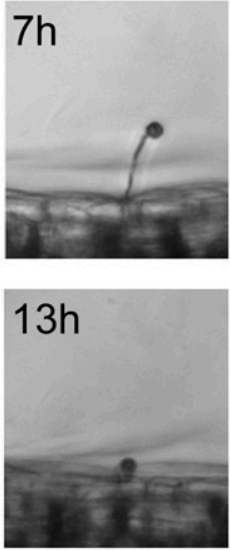

PI
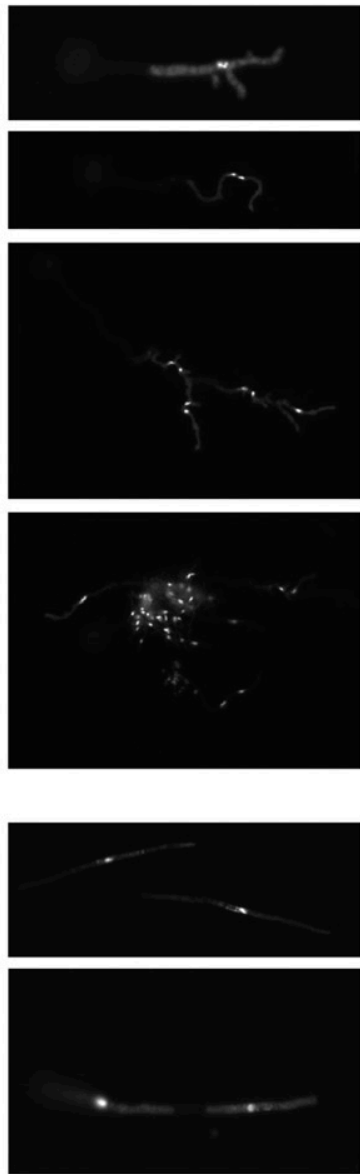
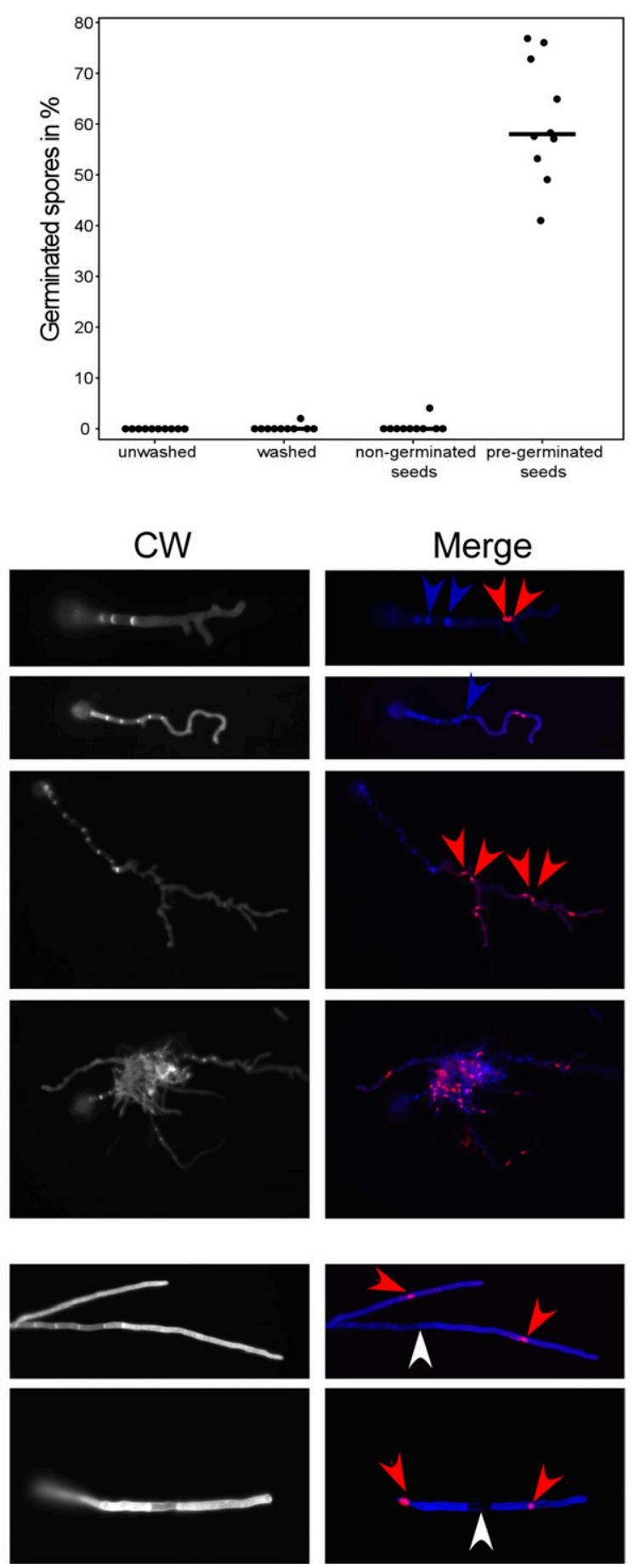

Fig. 2. Germination of Thecaphora thlaspeos teliospores. A, Teliospores germinate in the presence of seedlings (here Arabidopsis thaliana Col-0) and hyphae are growing toward the elongating root. Attachment to the root can be observed 12 to $13 \mathrm{~h}$ after spore germination and leads to drift of the spore away from its initial location $(13 \mathrm{~h})$. Scale bar: $50 \mu \mathrm{m}$. Quantification of the germination rate is shown on the right. Unwashed and washed teliospores were inoculated for 4 days in water, with nongerminating seeds or with pregerminated seeds; 1,000 spores per individual and treatment from 10 spore samples were surveyed. Bars indicate average rates of germination estimated. B, Early stages of T. thlaspeos spore germination and nuclear content after propidium iodine (PI) (red arrowheads) staining. Filaments emerging from the teliospore contain 1 or 2 nuclei and grow by inserting septa at the basal pole (shown by Calcofluor white staining [CW], blue arrowheads). Prolonged incubation ( $>14$ days) in the absence of a host plant results in distorted growth of the filaments and the formation of clumps. C, Vigorous shaking of such clumps leads to isolation of haploid filaments, which divide mitotically and separate, leaving behind empty sections (white arrowheads). These filaments form compact colonies when plated on solid media. Scale bar, $10 \mu \mathrm{m}$. 
resulted in compact colonies that were exclusively monokaryotic (Fig. 2C; Supplementary Movie S2).

In summary, $T$. thlaspeos teliospores develop infectious filaments that are not arrested in cell cycle and that can differentiate into monokaryotic mycelial cultures.

\section{T. thlaspeos mating genes are conserved.}

Shotgun genome sequencing of T. thlaspeos teliospores revealed $5 \mathrm{~Gb}$ of primary sequence information that was assembled into contigs. Fungal contigs contained homologs of the mating genes: the pheromone receptor genes pral and pra2, lipopeptide pheromone-encoding genes $m f a l$ (Bölker et al. 1992), as well as the $\mathrm{HD}$ transcription factor genes $b W$ and $b E$ from $U$. maydis (Kämper et al. 1995). All sequences were confirmed by amplification from genomic DNA of fungal cultures.

The predicted $T$. thlaspeos pheromone receptor genes (Ttpra) contain three (Ttpral) and two (Ttpra2) introns. TtPra1 and TtPra2 both span 388 amino acids (Fig. 3A). Maximum likelihood phylogeny placed TtPra1 in the Pra1 clade (46\% identity, $65 \%$ similarity between $T$. thlaspeos and $U$. maydis) and TtPra2 in the Pra2 clade (43\% identity, $64 \%$ similarity) of pheromone receptors (Supplementary Fig. S3A). Polymerase chain reaction (PCR) screening for pral and pra2 genes in spore samples from geographically distant populations revealed the presence of both genes in all tested spore samples (Fig. 3B). Interestingly, monokaryotic filamentous cultures that were isolated from these spore samples were either $a 1$ or $a 2$ mating types (Fig. 3B), suggesting that our axenic cultures are haploid for the $a$ locus. Although the tested spore samples contained the same two alleles of pra, the presence of additional, yetunidentified pra genes in T. thlaspeos, as observed in many other smut fungi (Kellner et al. 2011), cannot be excluded.

The predicted pheromone genes Ttmfal and Ttmfa2 are 126 and $117 \mathrm{bp}$ in length, with no introns (Fig. 3C). Both proteins, TtMfa1 and TtMfa2, have a C-terminal CaaX motif (Spellig et al. 1994) and a potential Kex 2 cleavage site (Bader et al. 2008; Brown and Casselton 2001). With 12 and 9 amino acids, the predicted mature pheromones Tta1 and Tta2 are of comparable size to $U$. maydis homologs Uma1 and Uma2. Of the four functionally important amino acid residues in $U$. maydis pheromones (Szabo et al. 2002), only proline (P7) and glycine (G9) are conserved (Fig. 3C).

The presence of homologs for the mating genes of smut fungi suggested the occurrence of mating also in T. thlaspeos. Indeed, a mating assay showed that filaments of opposite mating types grew toward each other, fused at their tips, and continued growth with a single filament (Fig. 3D). Furthermore, pheromones and receptors are expressed in axenic culture (Fig. 3E).

$T t b E$ and $T t b W$ were identified based on their conserved homeobox sequence and homologous gene orientation (Fig. 4A). Both are expressed in axenic culture (Fig. 3E). The HD DNA-binding sequences in TtbE and TtbW are well-conserved compared with $U$. maydis ( $82 \%$ amino acid similarity). In addition to the N-terminal variable domain similarity also dropped below $50 \%$ in parts of the more conserved C-terminus. In particular, the activation domain of UmbW1 (Kämper et al. 1995) and the predicted nuclear localization sequence in $\mathrm{bE}$ proteins are more variable in $T$. thlaspeos (Supplementary Fig. S4).

Overall, the presence of mating genes typical for smut fungi suggests a conservation of genetic exchange despite the morphological differences.

\section{T. thlaspeos HD transcription factors form hetero- and homodimers.}

To investigate the interaction of $\mathrm{bE}$ and $\mathrm{bW}$ homologs in T. thlaspeos in comparison with HD transcription factors of U. maydis (Kämper et al. 1995), a yeast two-hybrid approach was performed. As N-terminal fusions of the Gal4-DNAbinding (BD) domain to full-length $T t \mathrm{bW} 1$ and $T t \mathrm{bW} 2$ were auto-active (Supplementary Fig. S5C), we used N-terminal fusions of the GAL4-activation domain (AD) in our yeast twohybrid screens. In the test for dimer formation, full-length BD-TtbE and AD-TtbW interacted only when the two proteins originated from different alleles (Fig. 4C). Combining the N-termini of TtbE1 and TtbW 2 or TtbE2 with TtbW 1 showed that interallele-specific interaction is mediated by the variable domain of the proteins (Fig. 4B and C), which is typical for basidiomycetes (Casselton and Olesnicky 1998; Kämper et al. 1995).

Unexpectedly, besides the conserved interallelic heterodimerformation between $\mathrm{TtbE}$ and $\mathrm{TtbW}, \mathrm{TtbE}$ proteins are also able to form homodimers. Homodimerization is independent of the allele, as TtbE1 can interact with itself and with TtbE2. This is not the case for UmbE1 and UmbE2 (Fig. 4C). In contrast to the bE-bW interaction mediated by the variable domain, homodimerization of TtbE1 proteins takes place in the conserved domain, which includes the HD (amino acids 125 to 460) (Fig. 4B and $\mathrm{C}$ ).

Taken together, the $b$ locus controlling the dimorphic switch in grass smuts seems to be functionally conserved in T. thlaspeos. However, TtbE proteins can form homodimers raising questions about the nature of the complex, for example, as a tetramer or additional functions of TtbE in the fungal lifecycle. Further studies await genetic manipulation of $T$. thlaspeos to test for deletion phenotypes.

\section{T. thlaspeos establishes a systemic infection along the vasculature.}

To characterize the growth of $T$. thlaspeos within its host plants, we harvested a variety of tissues from infected plants during annual collections and visualized the presence of fungal hyphae via wheat germ agglutinin fluorescein isothiocyanate (WGA-FITC)/propidium iodide (PI) staining. All tested tissues, such as roots, rosette leaves, shoot leaves, flowers, and siliques, were colonized (Fig. 5) and T. thlaspeos grew systemically along the vasculature. To exclude that the stained fungal structures are part of the microbiome (De Coninck et al. 2015; Horton et al. 2014), we additionally confirmed their identity as T. thlaspeos by PCR, using T. thlaspeos-specific intergenic transcribed spacer primers.

We further characterized the colonization process in infection experiments with teliospores. Upon coincubation of fungal spores and Arabis hirsuta seeds, T. thlaspeos hyphae were detectable in seedlings grown under sterile conditions after three weeks as well as in adult, soil-grown plants (Fig. 6). As in the collected samples (Fig. 5), infection was restricted to the vasculature in all growth conditions (Fig. 6) and no macroscopic symptoms appeared. Interestingly, the hyphae in adult plants were fragmented near the base of the leaf and continuous near the fungal growth apexes (Fig. 6B). To induce flowering, Arabis hirsuta required a vernalization period of 12 weeks. During this time, hyphae remained in the leaves and showed both fragmented and continuous hyphae (Fig. 6A). After vernalization, inflorescences emerged, in which fungal structures were detected. Similar to the plants collected from nature, hyphae grew into flowers and siliques, in which they differentiated into viable spores (Fig. 6A), which again germinated to infect a new generation of plants. Hence, the life cycle can be completed under controlled conditions.

In our infection experiments, the seedling is entirely exposed to fungal spores, allowing the fungus to enter into any tissue. At early stages of cogermination, fungal hyphae grew toward the root tip, attached to the surface to penetrate the outer layers, and grew toward the vasculature (Fig. 7A). At later stages, 
T. thlaspeos proliferated from the root throughout the whole seedling along the vasculature. In some cases, fungal hyphae also wrapped around the root tip prior to penetration but, unlike $S$. reilianum, $T$. thlaspeos did not proliferate into a thick fungal layer upon penetration (Martinez et al. 2000) nor form pseudohyphae composed of yeast-like cells (Martinez et al. 2000). To test for the entry of T. thlaspeos into aerial tissues, spores were dropped on cotyledons of one-week-old Arabis hirsuta seedlings. After 4 days, spores had germinated and appressorialike structures were formed at the apical pole of the germ tubes (Fig. 7A; Supplementary Fig. S6).
T. thlaspeos establishes a systemic infection along the vasculature of both roots and shoots of Arabis hirsuta. Further, a robust method for infection under controlled conditions based on cogermination of spores and seeds was developed that reflects the natural infection process and allows completion of the life cycle.

\section{T. thlaspeos infects the model plant $A$. thaliana.}

Important insights into the plant immune system come from studies of the model plant A. thaliana (Asai and Shirasu 2015). While T. thlaspeos teliospores have not been reported in
A

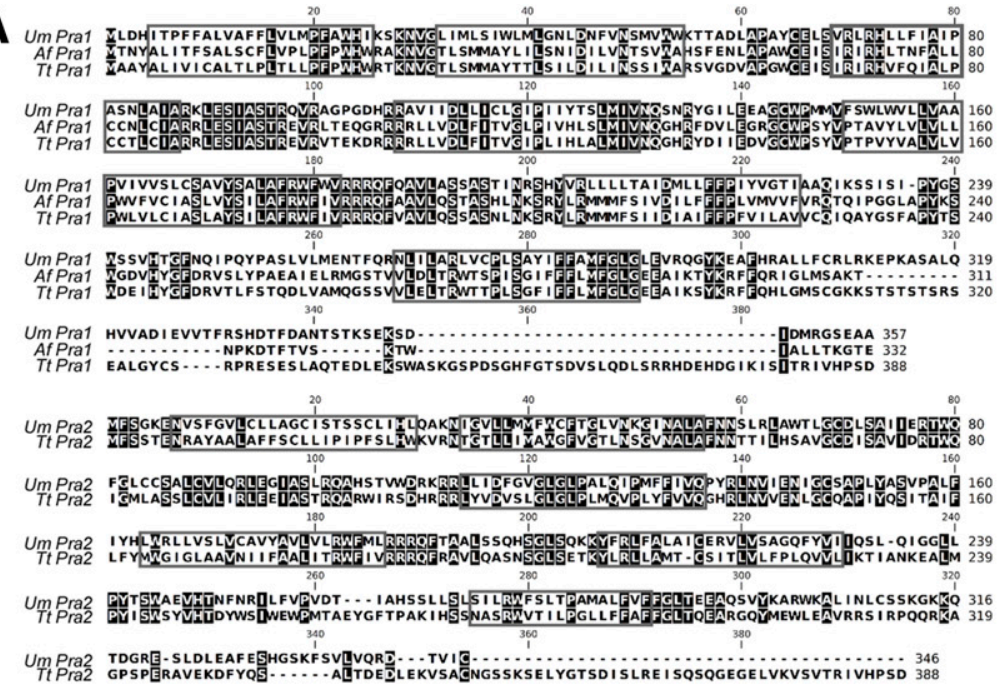

B

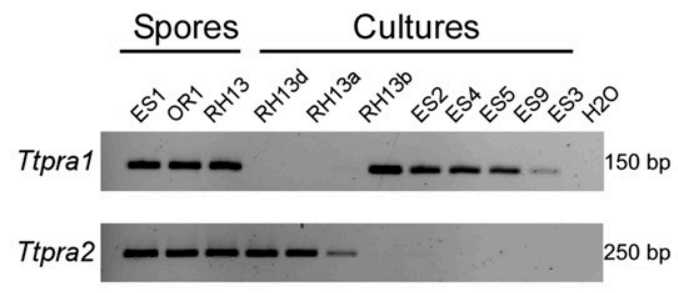

C

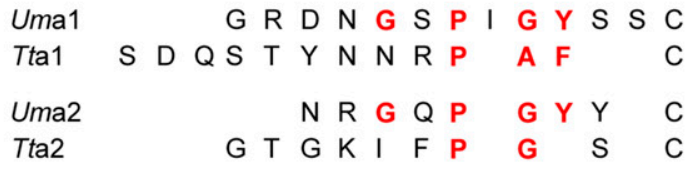

$\mathbf{E}$

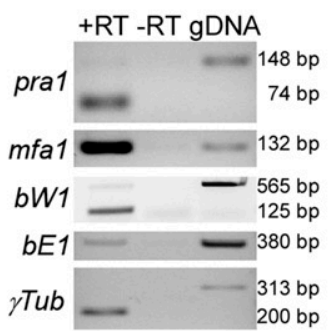

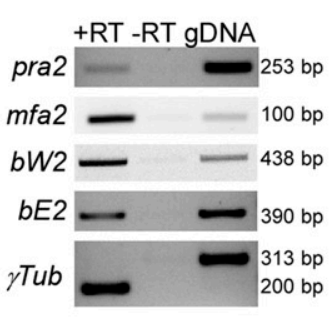

D
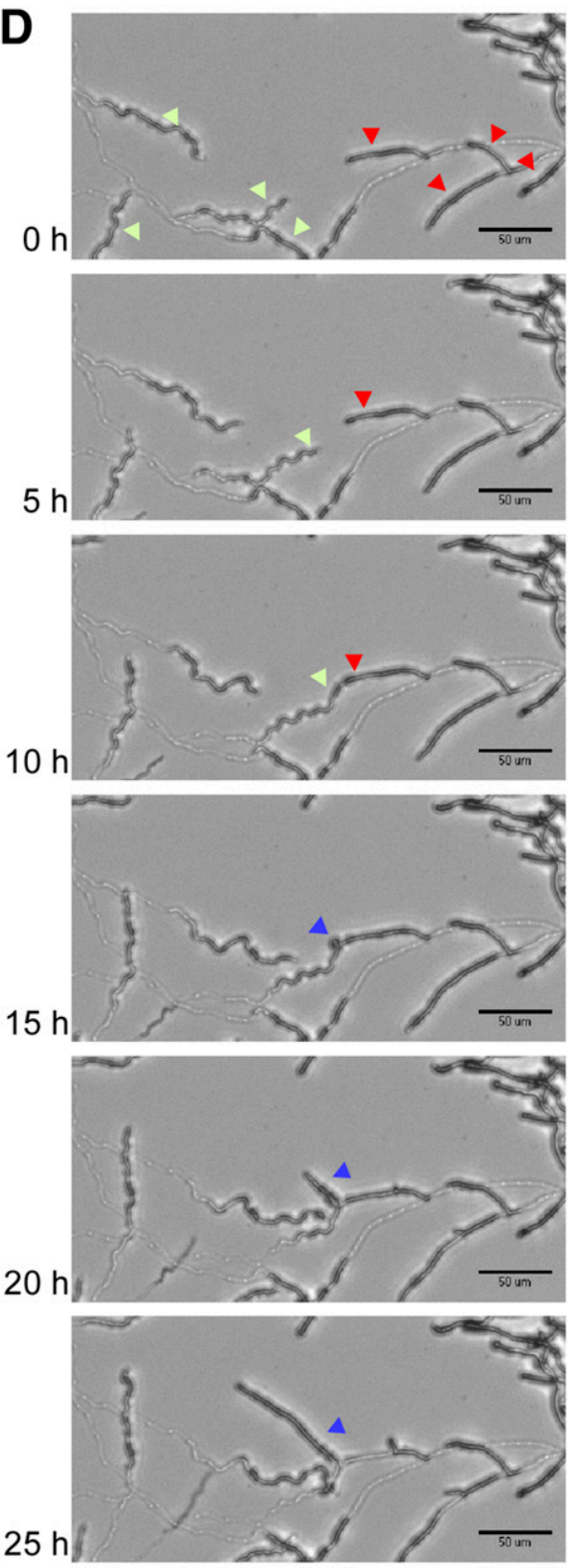

Fig. 3. The $a$ mating locus of Thecaphora thlaspeos. Shotgun genome sequencing of T. thlaspeos spores revealed homologs of the genes encoded in the a loci in Ustilago maydis: pral, pra2, and mfa1. A, Amino acid alignments of the predicted T. thlaspeos TtPra1 with the corresponding U. maydis (UMAG_02383) and Anthracocystis flocculosa (PFL1_01711) homologs and T. thlaspeos TtPra2 with the corresponding U. maydis homolog (AAA99768.1). Gray boxes show the transmembrane domains as predicted in the U. maydis sequences (TMHMM Server v 2.0). Highlighted squares show conserved amino acids. B, Polymerase chain reaction (PCR) with Ttpral/Ttpra2 specific markers reveals that spores from different strains contain both mating types. Cultures of isolated filaments derived from these spores are haploid. C, The predicted T. thlaspeos mature pheromones contain two out of the four functionally important amino acids (red). D, For the mating assay, cultures of the $a 1 b 1$ strain LF1 (green arrowheads) and the $a 2 b 2$ strain LF2 (red arrowheads) were dropped in close proximity on plates and were monitored for interaction over $73 \mathrm{~h}$. Filaments fused and continued growing in a single hybrid filament (blue arrowheads). E, Reverse transcription PCR on the cultures shows expression of the $a$ and $b$ mating genes in the haploid cultures LF1 and LF2. $\gamma$ Tubulin ( $\gamma$ Tub) was used as a control. 
A. thaliana siliques in more than a century of collections, in cogermination assays, T. thlaspeos infected the ecotype Col-0. Colonization resembled systemic infection of the natural host Arabis hirsuta, in that T. thlaspeos entered via roots, formed appressoria on leaves, and fungal hyphae systemically spread along the vasculature (Fig. 7B). Interestingly, we could not observe sporulation in $A$. thaliana siliques. Thus, early events in the infection process of $A$. thaliana are identical to the natural host Arabis hirsuta, making this model plant an ideal experimental host.

\section{DISCUSSION}

Smut fungi are important pathogens of crop plants that were investigated for decades (Kronstad 1996). The corn smut fungus $U$. maydis has developed into a model system for fungal infection biology (Martinez-Espinoza et al. 2002) and was selected among the top ten fungal pathogens (Dean et al. 2012). Its host plant, Zea mays, is agriculturally highly relevant with an annual corn production of $>300,000$ metric tons in the United States and $>50,000$ metric tons in Europe (IndexMundi website). However, its complex 2.5-Gb tetraploid genome (Wei et al. 2007) still makes genetic studies of host responses challenging. Therefore, we set out to describe a new smut infection system for Brassicaceae, using T. thlaspeos as the fungal partner.

\section{The life cycle of $T$. thlaspeos.}

To gain insight into the biology of $T$. thlaspeos, we initially characterized its life cycle (Fig. 8). Teliospores develop in the siliques of the host plant, either replacing or covering the seeds. Interestingly, mature teliospores depend on a plant signal to induce germination, while spores of all characterized smut fungi germinate readily in water. Stimulation of germination or presymbiotic development by plant-derived compounds is known in other fungi, e.g., monoterpenes stimulate spore germination in Verticillium longisporum (Roos et al. 2015), strigolactones induce hyphal branching (Akiyama et al. 2005), and flavonoids stimulate hyphal growth (Becard et al. 1992) in arbuscular mycorrhizal fungi. However, these compounds are heat-labile, while the signal inducing $T$. thlaspeos germination is heat-stable, indicating that a novel perception pathway might be involved in this species. In the future, we will identify the plant signal and the fungal signal perception pathways, making use of the qualitative nature of teliospore germination in T. thlaspeos.

Upon successful germination, filaments emerge from the T. thlaspeos teliospore (Fig. 8) that can directly penetrate the host plant via leaves and roots. Similarly, teliospores from the pearl millet smut Moesziomyces penicillariae germinate in a solo-pathogenic diploid form that, most likely, is an adaptation to the rapid life cycle of its host (Diagne-Leye et al. 2013). In contrast to dikaryotic filaments of dimorphic model smut fungi (Begerow et al. 2014; Perez-Martin et al. 2006), T. thlaspeos infectious filaments are not arrested in cell cycle but can differentiate into monokaryotic mycelial cultures of opposite mating types (Fig. 2). Importantly, only cultures of opposite mating types fuse to develop a potentially infectious, dikaryotic filament (Fig. 3). The capability to perform both, either direct infection from a single spore or outcrossing before infection, might be an adaptation of $T$. thlaspeos to its specific ecological niche. In particular, spatiotemporal dynamics of host resistances and pathogen virulences in rather disconnected host populations might have selected for the persistence of outcrossing, while the occasional spread of $T$. thlaspeos spores together with seeds facilitates infection without outcrossing (Jousimo et al. 2014; Karl and Koch 2014; Morran et al. 2011). In addition, hyphae persist in the vegetative tissue of the perennial host and repeatedly deposit spores when the plant flowers in consecutive years. Hence, T. thlaspeos adapted its
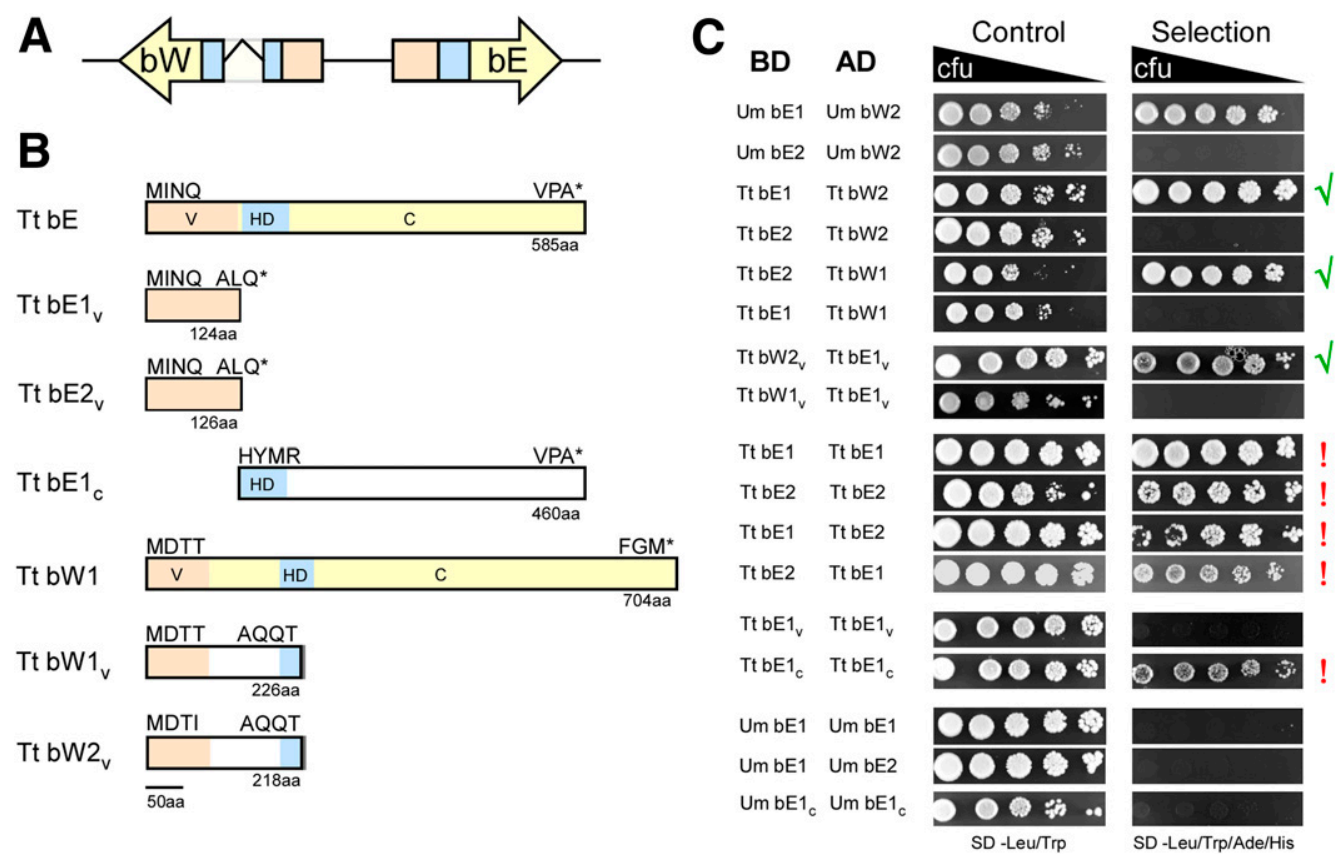

Fig. 4. The $b$ mating locus of Thecaphora thlaspeos is conserved. The $b$ locus was identified based on homology in sequence and organization of HD domains in the $\mathrm{b}$ proteins. Interaction of the b proteins was tested in a yeast two-hybrid assay. A, Schematic representation of the $b$ mating locus of $T$. thlaspeos: red, variable regions; yellow, conserved regions; blue, homeobox; and white box, intron of TtbW. B, Schematic representation of the constructs used in the yeast two-hybrid assay. C, T. thlaspeos bE and bW present the same heterodimer formation behavior as described in Ustilago maydis (green). However, bE in T. thlaspeos can form homodimers with itself as well as with other bE alleles (red). The heterodimer formation in T. thlaspeos is governed by the variable domains of $\mathrm{bE}$ and $\mathrm{bW}$, as demonstrated in $U$. maydis, while, for the T. thlaspeos bE homodimer formation, the conserved part of the protein might have a role. 
biotrophic interaction to sustain extreme seasonal abiotic changes and to overwinter together with its perennial host plant.

\section{Mating genetics of $T$. thlaspeos.}

For most plant-pathogenic smut fungi, sexual fusion of compatible haploid mating types is mandatory to initiate pathogenic growth (Feldbrügge et al. 2004; Fisher 1957; Kellner et al. 2011). Consistently, following spore germination, T. thlaspeos can be cultured in haploid mycelial cultures of two opposite mating types that grew toward each other, fused, and further proliferated as filaments, indicative of sexual fusion events (Fig. 3B and C). However, unlike the model species
U. maydis and S. reilianum, T. thlaspeos did not develop yeastlike sporidia from germinated spores.

Crucial genetic components are the pheromone/pheromone receptor system, which regulates sensing of compatible mating partners, and heterodimerizing transcription factors, which initiate pathogenic growth after fusion in smut fungi (Casselton and Feldbrügge 2010). T. thlaspeos encodes and expresses homologs of these genes (Figs. 3 and 4). Initial screening of teliospores from different populations (Fig. 3C) showed the presence of two pra alleles that are more distantly related as well as two $b$ alleles. Further analysis of mating genes in other fungi of the Thecaphora clade will contribute to characterizing

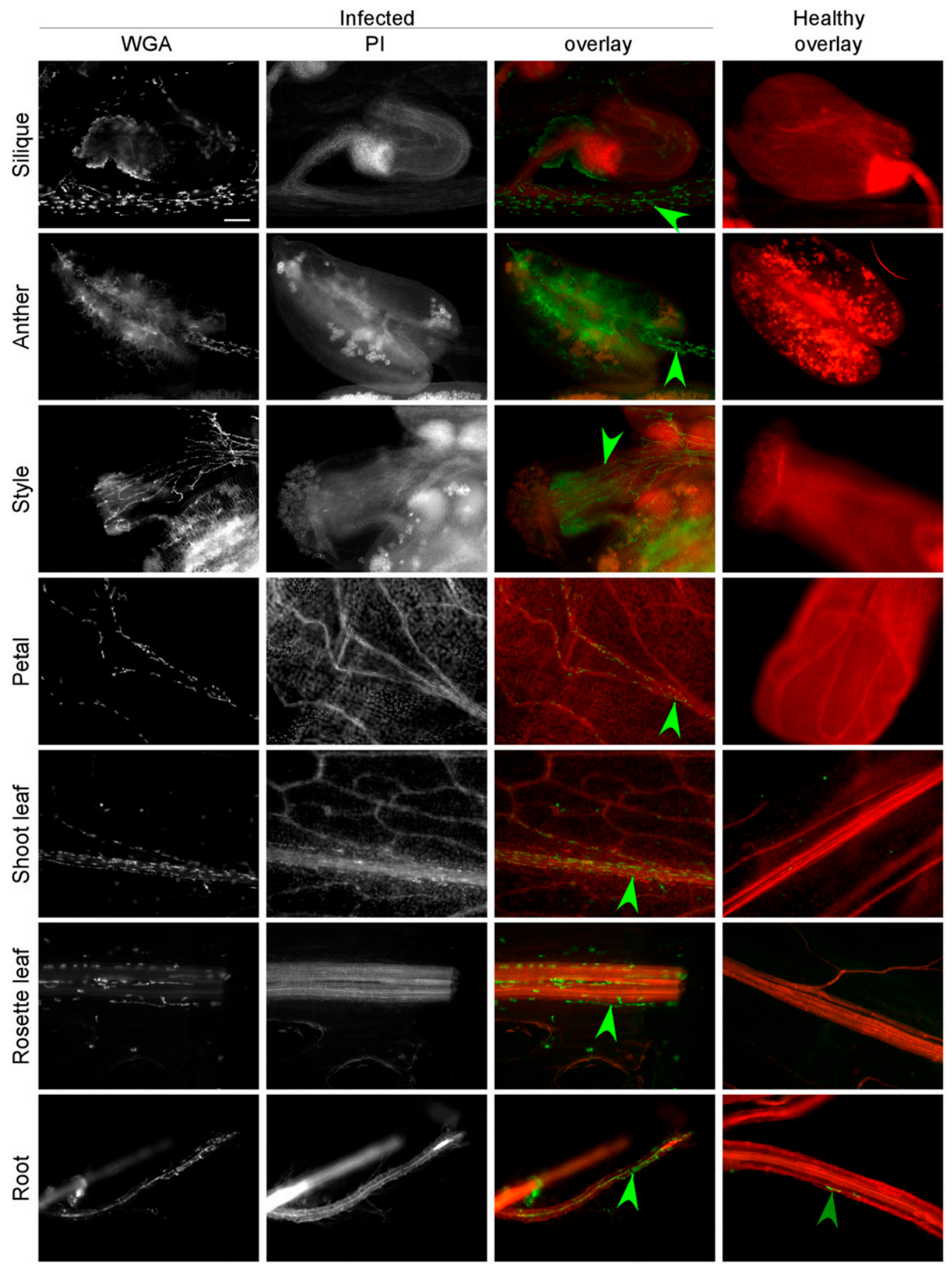

Fig. 5. Thecaphora thlaspeos systemically colonizes Arabis hirsuta in nature. In infected plants collected in Germany, fungal hyphae grow into all tissues, in which they are found predominantly along the main vasculature. Tissues were stained with wheat germ-agglutinin (WGA)-fluorescein isothiocyanate ( green) and propidium iodide (PI) (red). Green arrowheads indicate fungal hyphae. Scale bar, $100 \mu \mathrm{m}$. 
the ancestral state of the mating locus. Interaction studies of the heterodimerizing transcription factors showed smut-typical cross-compatibilities between $\mathrm{bE}$ and $\mathrm{bW}$ from opposite mating types (Fig. 3). Interestingly, bE1 and bE2 of T. thlaspeos additionally formed homodimers with themselves and each other (Fig. 4). This might indicate that they have a function outside of mating that is not known from other smuts. Similarly, the pheromone receptor Ste2 of Fusarium oxysporum gained an additional function to pheromone sensing by also sensing elusive plant signals that trigger directed hyphal growth toward plant roots (Turrà et al. 2015). Alternatively, the active bE/bW complex in $T$. thlaspeos might be multimeric, containing multiple bE proteins.

In summary, our findings suggest that $T$. thlaspeos has an active mating system that would allow exchange of genetic material.

\section{T. thlaspeos: a future model pathogen?}

Our aim was to develop a smut pathosystem with a genetically tractable host, such as A. thaliana (Provart et al. 2016), to utilize the genetic resources for molecular characterization of infection and plant responses. A. thaliana is an excellent experimental host for the investigation of molecular interactions of several pathogenic fungi, e.g., Fusarium spp. (Urban et al. 2002), Verticillium longisporum (Roos et al. 2015), Ustilaginoidea virens (Andargie and Li 2016), Botrytis cinerea (Thomma et al. 1999), and Magnaporthe oryzae (Park et al. 2009). T. thlaspeos is the only known smut fungus of Brassicaceae that can infect, among others, the sequenced perennial species Arabis alpina and A. lyrata subsp. petraea (Vánky 1994, 2012). Interestingly, under lab conditions, T. thlaspeos colonized A. thaliana, enabling use of the genetic tools of this model plant for molecular characterization. Together, the recent genome resources from the 1,001 genomes project in $A$. thaliana and novel genome editing techniques used in natural Brassicaceae hosts (Koenig and Weigel 2015) will enable us to compare the dynamics of infection in the different genetically tractable host plants.

In contrast to many other biotrophic pathogens, $T$. thlaspeos can be grown in haploid axenic cultures (Fig. 2). This cultivation of single-cell descendent isolates is the first step toward genetic manipulation. Transformation protocols have been successfully transferred between smut fungi, in which homologous recombination is highly efficient (Cervantes-Chavez et al. 2011; Schirawski et al. 2005; Yu et al. 2015). Recently, transformation of $U$. bromivora, the grass model Brachypodium distachyon, also was achieved (Rabe et al. 2016) yielding another interesting monocot model species in a smut pathosystem for comparative research.
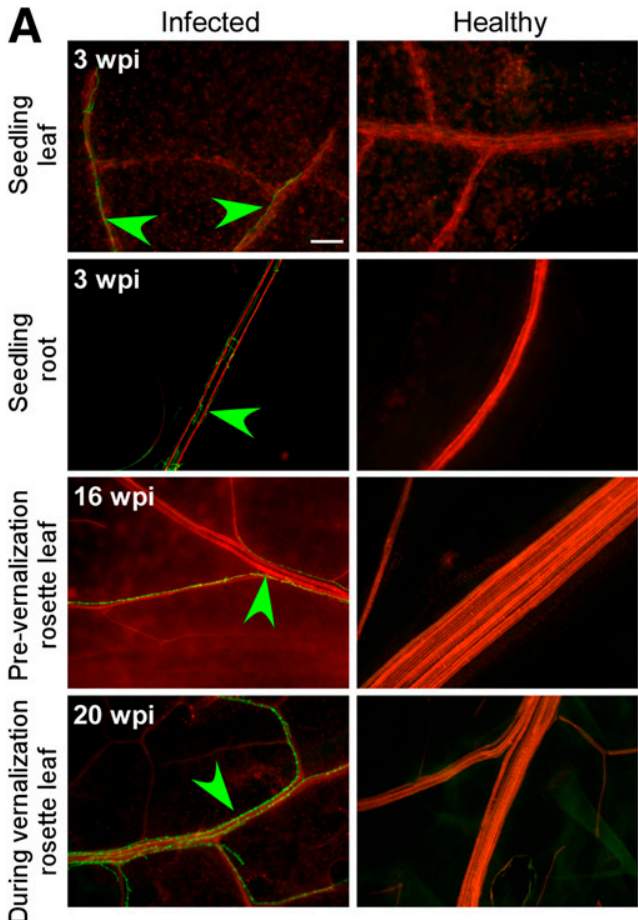

B
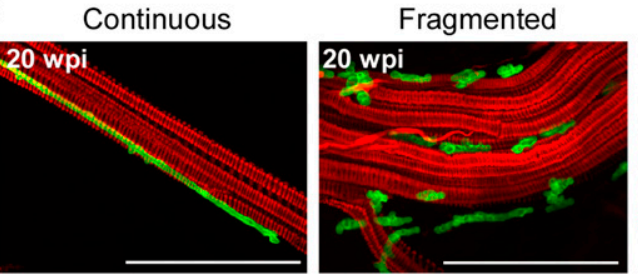
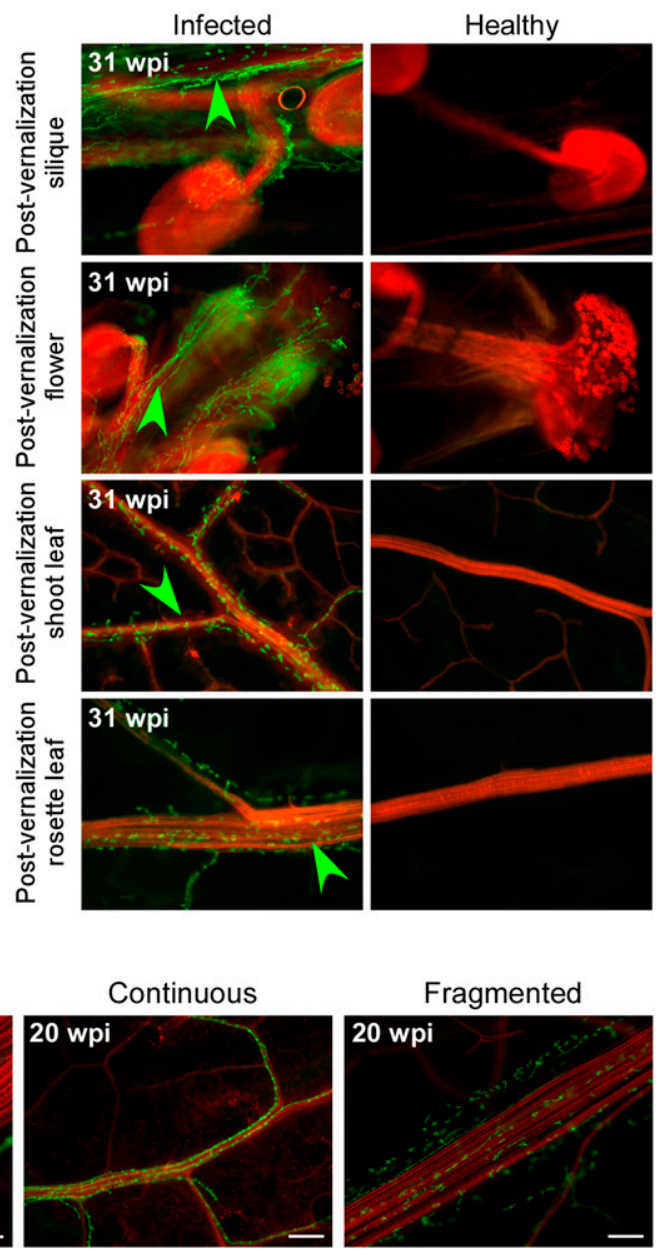

Fig. 6. Thecaphora thlaspeos systemically infects Arabis hirsuta under controlled conditions. A, Hyphal proliferation was observed in leaf and root tissues at the seedling stage and in adult rosette tissue prior to and during vernalization. Furthermore, during the flowering stage, spores were present in silique tissue and hyphal proliferation was observed in flower, shoot leaf, and rosette leaf tissues. B, Infection (here in rosette tissue) appears as both continuous and fragmented hyphae. Fungal growth in all images is predominantly along the main vasculature. Tissues were stained with wheat germ-agglutinin (WGA)-fluorescein isothiocyanate (green) and propidium iodide (PI) (red). Green arrowheads indicate fungal hyphae. Scale bar, $100 \mu \mathrm{m}$. 
T. thlaspeos is the first member of the Thecaphora clade that is analyzed in molecular detail. Fungi of this clade are of great agronomic relevance, e.g., the potato pathogen $T$. solani causes yield losses of up to $80 \%$ in South America and the peanut pathogen T. frezii causes yield losses of up to $51 \%$ (Conforto et al. 2013). To prevent its spread, T. solani is strictly quarantined by the European and Mediterranean Plant Protection Organization (OEPP/EPPO 1979). Markedly, T. solani teliospores also germinate with filaments (Andrade et al. 2004) and our research on the infection biology of the closely related T. thlaspeos could stimulate the development of novel strategies aiming to protect potato production in Europe.

T. thlaspeos has evolved a long-lasting, tight interaction with its perennial host plants, in which it is capable of overwintering. We speculate that this requires special adaptations in order to balance virulence, a characteristic typical of microbial plant endophytes (Schulz and Boyle 2005). The molecular characterization of such determinants could improve, e.g., production of Jiaobai, swollen stems caused by growth of U. esculenta in the wild rice Zizania latifolia (Terrell and Batra 1982). To date, the fungus has to be maintained in the plant by agricultural practice, but selection has already shaped the genome of the host plant toward reduced defense (Guo et al. 2015).

Beneficial effects of endophytes on their host plants are of particular interest for crop improvement (Aly et al. 2011). For example, systemic colonization by the ascomycete genus Epichlo $\ddot{e}$ improves resistance of Pooideae grasses to biotic and

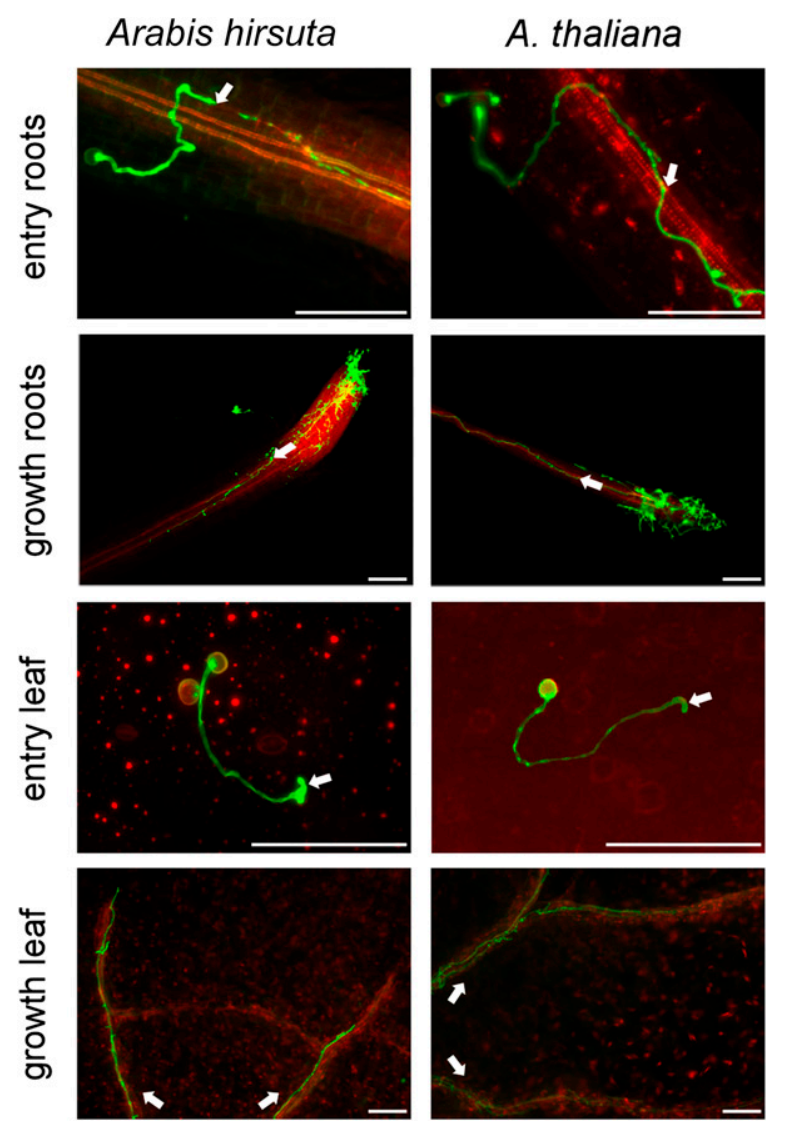

Fig. 7. Entry of Thecaphora thlaspeos into roots and leaves are identical in the host Arabis hirsuta and the model plant Arabidopsis thaliana. T. thlaspeos penetrates root and leaf tissues of seedlings, subsequently growing along the main vasculature in both species. No differences between the natural host plant Arabis hirsuta and the experimental host A. thaliana are detectable. Tissues were stained with wheat germ-agglutinin (WGA)-fluorescein isothiocyanate (green) and propidium iodide (PI) (red). White arrows indicate penetration sites or direction of hyphal growth. Scale bar, $100 \mu \mathrm{m}$. abiotic stresses. Therefore, a number of strains are already used as biocontrol agents in agriculture (Johnson et al. 2013). Investigating potentially beneficial effects of $T$. thlaspeos in its Brassicaceae host might lead to agricultural applications in Brassicaceae crops in the future. Further, T. thlaspeos and the variety of its genetically tractable Brassicaceae host plants, including both annuals and perennials, serve as a promising model to disentangle the molecular determinants of long-lived systemic interactions as well as factors involved in specific resistances of one or both annuals and perennials. Examples like the Sileneinfecting anther smut fungus Microbotryum violaceum show that closely related annual and perennial plant species differ in susceptibility to the same pathogen in the field but can both be infected under natural conditions (Gibson et al. 2013; Hood et al. 2010).

In conclusion, T. thlaspeos is a valuable, novel pathogen to study the molecular communication of smut fungi with their hosts. It also will give insight into the establishment and maintenance of prolonged endophytic growth as well as differences in colonization between annual and perennial plants. Such detailed knowledge of smut infection strategies will ultimately contribute to the development of novel plant protection strategies.

\section{MATERIALS AND METHODS}

Spore germination, infection, and cultures.

T. thlaspeos teliospores from infected siliques were treated with ampicillin $(100 \mu \mathrm{g} / \mathrm{ml})$ for $24 \mathrm{~h}$ at room temperature. Sterilized seeds were mixed with these teliospores in halfstrength MSN medium (Duchefa) containing 1\% sucrose or in water, for quantification, and were incubated for 3 to 7 days $(12 \mathrm{~h}$,

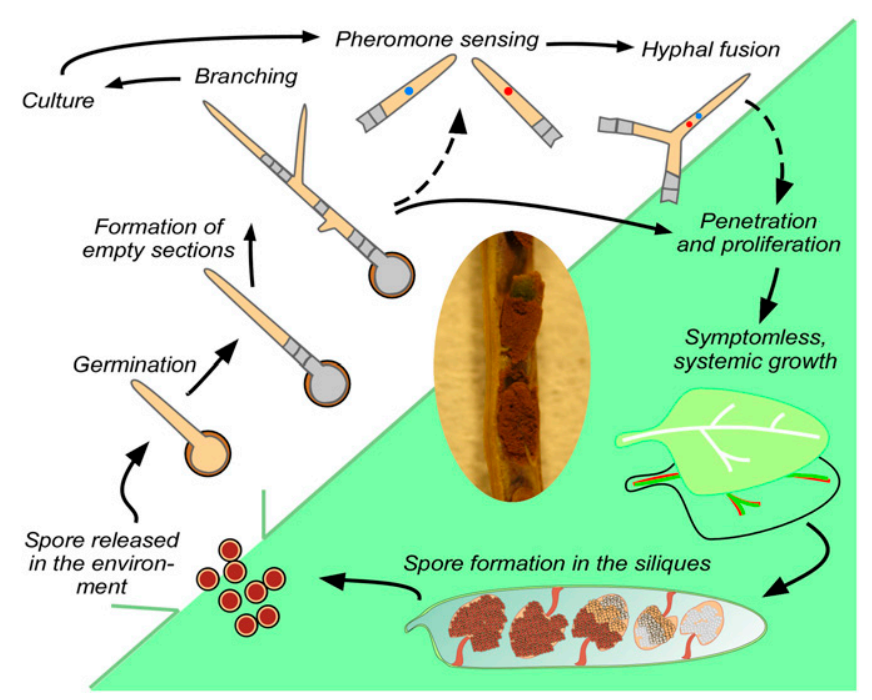

Fig. 8. Life cycle of Thecaphora thlaspeos. The macroscopic infection symptoms of $T$. thlaspeos are shown in the middle as seeds of the host covered in spores. Such teliospores are released into the environment or they propagate together with the seed. Upon perception of a to-dateunknown plant signal, the spores germinate in a filamentous form. In this stage, the resulting hyphae insert retraction septa, form empty sections, and hyphal branching occurs. Filaments can directly infect the plant or proliferate into haploid cultures of opposite mating type that can be grown in axenic culture. When two hyphae of compatible mating types are close in proximity, they sense each other, most likely via their pheromone-receptor system, and fuse at the tips, resulting again in a filament. Based on similarity to other smut fungi, these fusion filaments presumably are infectious (dashed arrow). Infectious fungal filaments can enter the plant directly via the root or form appressoria-like structures on leaves. T. thlaspeos systemically proliferates inside the plant tissue along the vasculature. Macroscopic infection symptoms are absent until the host produces seeds that are either coated or completely replaced by fungal teliospores. 
$100 \mu \mathrm{E}$ ), until seeds and spores germinated, or for 3 weeks, until the seedlings were infected. To obtain cultures, hyphal clumps were transferred to complete medium $(\mathrm{CM})+1 \%$ glucose (Holliday 1974) and were incubated on a shaker (200 rpm) at $16^{\circ} \mathrm{C}$. The medium was renewed every 5 days. After 1 month, $200 \mu \mathrm{l}$ of culture was plated on CM $+1 \%$ glucose plates. Single colonies were reisolated at least five times. Cultures resulting from these colonies were screened by PCR and were sequenced for $a$ and $b$ locus alleles, using primer pairs DD207 to DD210 and pair DD175 and DD15, respectively. Cultures that had a single allele for each mating type were kept (LF1: pra1, b1; LF2: pra2, b2). For leaf infection, approximately 100 spores in $1 \mu \mathrm{l}$ of $\mathrm{H}_{2} \mathrm{O}$ were pipetted onto the cotyledons of 7-day-old seedlings, were grown on MSN with sucrose, as described above, and were incubated for 4 to 12 days $(12 \mathrm{~h}, 100 \mu \mathrm{E})$. For soil infection, untreated seeds and spores were mixed. The spore-covered seeds were sown on soil, were stratified for 5 days, and were incubated in long day conditions ( $16 \mathrm{~h}, 125 \mu \mathrm{E})$. After approximately 6 weeks, plants were transferred to $4^{\circ} \mathrm{C}$ for vernalization for 12 weeks and returned to long day until flowering.

\section{Extraction of RNA and genomic DNA.}

To extract genomic DNA, the phenol-based method established for $U$. maydis was followed (Bösch et al. 2016). RNA was extracted from T. thlaspeos using the Qiagen RNAeasy kit (Qiagen) and cDNA was synthesized using the Protoscript kit (New England Biolabs), following manufacturers' instructions.

\section{Genomic sequencing and bioinformatics analysis.}

For the shotgun sequencing of T. thlaspeos, genomic DNA from teliospores of three infected siliques was extracted. The genomic sequencing library was constructed with the Nextera DNA sample preparation kit (Illumina), according to manufacturer's instructions. Quality control by analysis on an Agilent 2000 Bioanalyzer with Agilent high sensitivity DNA kit (Agilent Technologies) showed fragment sizes of 200 to $450 \mathrm{bp}$. Sequencing on a MiSeq sequencer (Illumina) $(2 \times 250 \mathrm{bp})$ was performed in the Genomics Service Unit (LMU Biocenter, Martinsried, Germany), yielding about 29 Mio paired reads and 5 $\mathrm{Gb}$ of primary sequence. The reads were assembled into 96,471 contigs, using CLC Genomics Server 5.0.2 (Qiagen), with the following parameters: word size, 23 ; bubble size, 172; mismatch cost, 2; insertion cost, 3; deletion cost, 3; length fraction, 0.5; similarity fraction, 0.8; minimum contig length, 200. Approximately $5 \%$ of the sequences corresponded to fungi (MG-RAST [Meyer et al. 2008]). The majority was bacterial and plant contamination. Alignments were performed using MUSCLE 3.8 via CLC Main Workbench 7.6.2 (Qiagen), and maximum likelihood phylogeny trees were performed, using CLC Main Workbench 7.6.2 with default parameter (Qiagen). Branches with bootstrap support lower than $60 \%$ were collapsed.

\section{Yeast two-hybrid assay.}

Yeast two-hybrid analysis was carried out using the Clontech MatchMaker system as described (Kämper et al. 1995; Pohlmann et al. 2015). Sequences for the clones were amplified from cDNAs of cultures containing the $b 1$ or the $b 2$ locus (Supplementary Tables S2 and S3).

\section{Staining and microscopy.}

Nuclear staining of filaments was carried out as described (Sabbagh et al. 2010). Staining of infected material by WGAFITC $(1 \mu \mathrm{g} / \mathrm{ml})$ and PI $(10 \mu \mathrm{g} / \mathrm{ml})$ was modified from Doehlemann et al. (2008), by shortening the boiling step to $3 \mathrm{~min}$. Staining by trypan blue was carried out as described by Kemen et al. (2005). Chitin of fungal cells on cotyledon tissue was stained by immersing plantlets in Calcofluor white $(\mathrm{CW})$ at $1 \mu \mathrm{g} / \mathrm{ml}$ for
1 min. For scanning electron microscopy, seedlings with spores on the cotelydons were fixed with $2.5 \%$ glutaraldehyde. Samples were dried via the critical point drying (CPD) technique, were mounted, and were coated with gold, using a sputter coater.

Fluorescence microscopy was performed as described by Langner et al. (2015) on a Zeiss Axio Immager M1. The movies were recorded on the same microscope. All parts of the microscope system were controlled by the software package MetaMorph (version 7; Molecular Devices), which was also used for image processing. Confocal microscopy was performed on the Zeiss LSM 780, using laser lines 488 and 561 for WGA-FITC and $\mathrm{PI}$, respectively, and image processing was conducted using the ZEN 2012 (black version) software package. Scanning electron microscopy was performed on the Leo $1430 \mathrm{VP}$.

\section{ACKNOWLEDGMENTS}

Special thanks to S. Weidtkamp-Peters and S. Köhler for help with confocal and scanning electron microscopy. Research in the laboratory of V. Göhre is funded by the Cluster of Excellence in Plant Sciences (CEPLAS, DFG EXC 1028) and the Bioeconomy Science Center (BioSC). The scientific activities of the BioSC were financially supported by the Ministry of Innovation, Science and Research within the framework of the NRW Strategieprojekt BioSC (number. 313/323-400-00213). R. Kellner and L. Plücker are supported by CEPLAS, L. Frantzeskakis and K. J. Courville are supported by a doctoral fellowship of the DFG International Research Training Group 1525 iGRAD-Plant

\section{LITERATURE CITED}

Akiyama, K., Matsuzaki, K. I., and Hayashi, H. 2005. Plant sesquiterpenes induce hyphal branching in arbuscular mycorrhizal fungi. Nature 435: 824-827.

Aly, A. H., Debbab, A., and Proksch, P. 2011. Fungal endophytes: Unique plant inhabitants with great promises. Appl. Microbiol. Biotechnol. 90: 1829-1845.

Andargie, M., and Li, J. 2016. Arabidopsis thaliana: A model host plant to study plant-pathogen interaction using rice false smut isolates of Ustilaginoidea virens. Front. Plant Sci. 7:192.

Andrade, O., Munoz, G., Galdames, R., Duran, P., and Honorato, R. 2004. Characterization, in vitro culture, and molecular analysis of Thecaphora solani, the causal agent of potato smut. Phytopathology 94:875-882.

Asai, S., and Shirasu, K. 2015. Plant cells under siege: Plant immune system versus pathogen effectors. Curr. Opin. Plant Biol. 28:1-8.

Bader, O., Krauke, Y., and Hube, B. 2008. Processing of predicted substrates of fungal Kex2 proteinases from Candida albicans, C. glabrata, Saccharomyces cerevisiae and Pichia pastoris. BMC Microbiol. 8:1-16.

Banuett, F. 1992. Ustilago maydis, the delightful blight. Trends Genet. 8: 174-180.

Baumgarten, A. M., Suresh, J., May, G., and Phillips, R. L. 2007. Mapping QTLs contributing to Ustilago maydis resistance in specific plant tissues of maize. Theor. Appl. Genet. 114:1229-1238.

Becard, G., Douds, D. D., and Pfeffer, P. E. 1992. Extensive in vitro hyphal growth of vesicular-arbuscular mycorrhizal fungi in the presence of $\mathrm{CO}_{2}$ and flavonols. Appl. Environ. Microbiol. 58:821-825.

Begerow, D., Schäfer, A. M., Kellner, R., Yurkov, A., Kemler, M., Oberwinkler, F., and Bauer, R. 2014. Ustilaginomycotina. The Mycota Vol. 7. Systematics and Evolution Part A. Springer Verlag, Berlin.

Bölker, M., Urban, M., and Kahmann, R. 1992. The $a$ mating type locus of U. Maydis specifies cell signaling components. Cell 68:441-450.

Bösch, K., Frantzeskakis, L., Vraneš, M., Kämper, J., Schipper, K., and Göhre, V. 2016. Genetic manipulation of the plant pathogen Ustilago maydis to study fungal biology and plant microbe interactions. J. Vis. Exp. 115:e54522.

Brefort, T., Doehlemann, G., Mendoza-Mendoza, A., Reissmann, S., Djamei, A., and Kahmann, R. 2009. Ustilago maydis as a pathogen. Annu. Rev. Phytopathol. 47:423-445.

Brewer, H. C., and Hammond-Kosack, K. E. 2015. Host to a Stranger: Arabidopsis and Fusarium ear blight. Trends Plant Sci. 20:651663.

Brown, A. J., and Casselton, L. A. 2001. Mating in mushrooms: Increasing the chances but prolonging the affair. Trends Genet. 17:393-400.

Casselton, L., and Feldbrügge, M. 2010. Mating and sexual morphogenesis in basidiomycete fungi. Pages 536-555 in: Cellular and Molecular 
Biology of Filamentous Fungi. K. Borkovich and D. Ebbole, eds. American Society of Microbiology, Washington, D.C.

Casselton, L. A., and Olesnicky, N. S. 1998. Molecular genetics of mating recognition in basidiomycete fungi. Microbiol. Mol. Biol. Rev. 62:55-70.

Cervantes-Chavez, J. A., Ali, S., and Bakkeren, G. 2011. Response to environmental stresses, cell-wall integrity, and virulence are orchestrated through the calcineurin pathway in Ustilago hordei. Mol. Plant-Microbe Interact. 24:219-232.

Conforto, C., Cazón, I., Fernández, F. D., Marinelli, A., Oddino, C., and Rago, A. M. 2013. Molecular sequence data of Thecaphora frezii affecting peanut crops in Argentina. Eur. J. Plant Pathol. 137:663-666.

Cook, D. E., Mesarich, C. H., and Thomma, B. P. H. J. 2015. Understanding plant immunity as a surveillance system to detect invasion. Annu. Rev. Phytopathol. 53:541-563.

De Coninck, B., Timmermans, P., Vos, C., Cammue, B. P. A., and Kazan, K. 2015. What lies beneath: Belowground defense strategies in plants. Trends Plant Sci. 20:91-101.

Dean, R., Van Kan, J. A. L., Pretorius, Z. A., Hammond-Kosack, K. E., Di Pietro, A., Spanu, P. D., Rudd, J. J., Dickman, M., Kahmann, R., Ellis, J., and Foster, G. D. 2012. The top 10 fungal pathogens in molecular plant pathology. Mol. Plant Pathol. 13:414-430.

Diagne-Leye, G., Sare, I. C., Martinez, Y., Fall-Ndiaye, M. A., Sabbagh, S. K., Ba, A. T., and Roux, C. P. 2013. The life cycle of the smut fungus Moesziomyces penicillariae is adapted to the short-cycle of the host, Pennisetum glaucum. Fungal Biol-Uk 117:311-318.

Doehlemann, G., Wahl, R., Vranes, M., de Vries, R. P., Kamper, J., and Kahmann, R. 2008. Establishment of compatibility in the Ustilago maydis/maize pathosystem. J. Plant Physiol. 165:29-40.

Feldbrügge, M., Kämper, J., Steinberg, G., and Kahmann, R. 2004. Regulation of mating and pathogenic development in Ustilago maydis. Curr. Opin. Microbiol. 7:666-672.

Fisher, G. W. H. C S. 1957. Biology and Control of the Smut Fungi. The Ronald Press Company, New York.

Fisher, M. C., Henk, D. A., Briggs, C. J., Brownstein, J. S., Madoff, L. C., McCraw, S. L., and Gurr, S. J. 2012. Emerging fungal threats to animal, plant and ecosystem health. Nature 484:186-194.

Gibson, A. K., Petit, E., Mena-Ali, J., Oxelman, B., and Hood, M. E. 2013. Life-history strategy defends against disease and may select against physiological resistance. Ecol. Evol. 3:1741-1750.

Grewal, T. S., Rossnagel, B. G., Bakkeren, G., and Scoles, G. J. 2008. Identification of resistance genes to barley covered smut and mapping of the Ruh1 gene using Ustilago hordei strains with defined avirulence genes. Can. J. Plant Pathol. 30:277-284.

Guo, L. B., Qiu, J., Han, Z. J., Ye, Z. H., Chen, C., Liu, C. J., Xin, X. F., Ye, C. Y., Wang, Y. Y., Xie, H. Q., Wang, Y., Bao, J. D., Tang, S., Xu, J., Gui, Y. J., Fu, F., Wang, W. D., Zhang, X. C., Zhu, Q. H., Guang, X. M., Wang, C. Z., Cui, H. F., Cai, D. G., Ge, S., Tuskan, G. A., Yang, X. H., Qian, Q., He, S. Y., Wang, J., Zhou, X. P., and Fan, L. J. 2015. A host plant genome (Zizania latifolia) after a century-long endophyte infection. Plant J. 83:600-609.

Hay, A. S., Pieper, B., Cooke, E., Mandáková, T., Cartolano, M., Tattersall, A. D., Ioio, R. D., McGowan, S. J., Barkoulas, M., Galinha, C., Rast, M. I., Hofhuis, H., Then, C., Plieske, J., Ganal, M., Mott, R., MartinezGarcia, J. F., Carine, M. A., Scotland, R. W., Gan, X., Filatov, D. A., Lysak, M. A., and Tsiantis, M. 2014. Cardamine hirsuta: A versatile genetic system for comparative studies. Plant J. 78:1-15.

Holliday, R. 1961. Genetics of Ustilago maydis. Genet. Res. 2:204-230.

Holliday, R. 1974. Molecular aspects of genetic exchange and gene conversion. Genetics 78:273-287.

Hood, M. E., Mena-Ali, J. I., Gibson, A. K., Oxelman, B., Giraud, T., Yockteng, R., Arroyo, M. T. K., Conti, F., Pedersen, A. B., Gladieux, P., and Antonovics, J. 2010. Distribution of the anther-smut pathogen Microbotryum on species of the Caryophyllaceae. New Phytol. 187:217-229.

Horton, M. W., Bodenhausen, N., Beilsmith, K., Meng, D., Muegge, B. D., Subramanian, S., Vetter, M. M., Vilhjálmsson, B. J., Nordborg, M., Gordon, J. I., and Bergelson, J. 2014. Genome-wide association study of Arabidopsis thaliana leaf microbial community. Nat. Commun. 5:5320.

Hu, G. G., Linning, R., and Bakkeren, G. 2002. Sporidial mating and infection process of the smut fungus, Ustilago hordei, in susceptible barley. Can. J. Bot. 80:1103-1114.

Ingold, C. T. 1988. Teliospore germination in some species of Ustilaginaceae. Trans. Br. Mycol. Soc. 91:505-514.

Ingold, C. T. 1989. Basidium development in some species of Ustilago. Mycol. Res. 93:405-412.

Ingold, C. T. 1992. Germination of teliospores and basidium formation in Ustilago. Mycologist 6:184.

Johnson, L. J., De Bonth, A. C. M., Briggs, L. R., Caradus, J. R., Finch, S. C., Fleetwood, D. J., Fletcher, L. R., Hume, D. E., Johnson, R. D.,
Popay, A. J., Tapper, B. A., Simpson, W. R., Voisey, C. R., and Card, S. D. 2013. The exploitation of Epichloae endophytes for agricultural benefit. Fungal Divers. 60:171-188.

Jousimo, J., Tack, A. J. M., Ovaskainen, O., Mononen, T., Susi, H., Tollenaere, C., and Laine, A. L. 2014. Ecological and evolutionary effects of fragmentation on infectious disease dynamics. Science 344:1289-1293.

Kämper, J., Reichmann, M., Romeis, T., Bölker, M., and Kahmann, R. 1995. Multiallelic recognition-Nonself-dependent dimerization of the $\mathrm{bE}$ and bW homeodomain proteins in Ustilago maydis. Cell 81:73-83.

Karl, R., and Koch, M. A. 2014. Phylogenetic signatures of adaptation: The Arabis hirsuta species aggregate (Brassicaceae) revisited. Perspect. Plant Ecol. 16:247-264.

Kellner, R., Vollmeister, E., Feldbrügge, M., and Begerow, D. 2011. Interspecific sex in grass smuts and the genetic diversity of their pheromone-receptor system. PLoS Genet. 7:e1002436.

Kemen, E., Hahn, M., Mendgen, K., and Struck, C. 2005. Different resistance mechanisms of Medicago truncatula ecotypes against the rust fungus Uromyces striatus. Phytopathology 95:153-157.

Kent, C. R., Ortiz-Bermúdez, P., Giles, S. S., and Hull, C. M. 2008 Formulation of a defined V8 medium for induction of sexual development of Cryptococcus neoformans. Appl. Environ. Microbiol. 74:62486253.

Knox, R. E., Campbell, H. L., Clarke, F. R., Menzies, J. G., Popovic, Z., Procunier, J. D., Clarke, J. M., Depauw, R. M., Cuthbert, R. D., and Somers, D. J. 2014. Quantitative trait loci for resistance in wheat (Triticum aestivum) to Ustilago tritici. Can. J. Plant Pathol. 36:187-201.

Koenig, D., and Weigel, D. 2015. Beyond the thale: Comparative genomics and genetics of Arabidopsis relatives. Nat. Rev. Genet. 16:285-298

Kronstad, J. W. 1996. Pathogenesis and sexual development of the smut fungi. Pages 141-186 in: Plant-Microbe Interactions. G. Stacey and N. T. Keen, eds. Springer US, Boston

Lacombe, S., Rougon-Cardoso, A., Sherwood, E., Peeters, N., Dahlbeck, D., van Esse, H. P., Smoker, M., Rallapalli, G., Thomma, B. P., Staskawicz, B., Jones, J. D., and Zipfel, C. 2010. Interfamily transfer of a plant pattern-recognition receptor confers broad-spectrum bacterial resistance. Nat. Biotechnol. 28:365-369.

Langner, T., Özturk, M., Hartmann, S., Cord-Landwehr, S., Moerschbacher, B., Walton, J. D., and Göhre, V. 2015. Chitinases are essential for cell separation in Ustilago maydis. Eukaryot. Cell 14:846-857.

Lanver, D., Berndt, P., Tollot, M., Naik, V., Vranes, M., Warmann, T., Munch, K., Rossel, N., and Kahmann, R. 2014. Plant surface cues prime Ustilago maydis for biotrophic development. PLoS Pathog. 10: e1004272.

Martinez-Espinoza, A. D., Garcia-Pedrajas, M. D., and Gold, S. E. 2002. The Ustilaginales as plant pests and model systems. Fungal Genet. Biol. 35:1-20.

Martinez, C., Roux, C., Jauneau, A., and Dargent, R. 2002. The biological cycle of Sporisorium reilianum $\mathrm{f}$. sp. zeae: An overview using microscopy. Mycologia 94:505-514.

Martinez, C., Jauneau, A., Roux, C., Savy, C., and Dargent, R. 2000. Early infection of maize roots by Sporisorium reilianum f. sp zeae. Protoplasma 213:83-92.

Mendoza-Mendoza, A., Berndt, P., Djamei, A., Weise, C., Linne, U., Marahiel, M., Vranes, M., Kamper, J., and Kahmann, R. 2009. Physicalchemical plant-derived signals induce differentiation in Ustilago maydis. Mol. Microbiol. 71:895-911.

Meyer, F., Paarmann, D., D’Souza, M., Olson, R., Glass, E. M., Kubal, M., Paczian, T., Rodriguez, A., Stevens, R., Wilke, A., Wilkening, J., and Edwards, R. A. 2008. The metagenomics RAST server-A public resource for the automatic phylogenetic and functional analysis of metagenomes. BMC Bioinformatics 9:386.

Morran, L. T., Schmidt, O. G., Gelarden, I. A., Parrish, R. C., and Lively, C. M. 2011. Running with the Red Queen: Host-parasite coevolution selects for biparental sex. Science 333:216-218.

Murashige, T., and Skoog, F. 1962. A revised medium for rapid growth and bio assays with tobacco tissue cultures. Physiol. Plant. 15:473-497.

OEPP/EPPO. 1979. Data sheets on quarantine organisms No. 4, Angiosorus solani. Bulletin OEPP/EPPO Bulletin 9. CABI Intl., Wallingford, U.K.

Oerke, E. C. 2006. Crop losses to pests. J. Agric. Sci. 144:31-43.

Park, J. Y., Jin, J. M., Lee, Y. W., Kang, S., and Lee, Y. H. 2009. Rice blast fungus (Magnaporthe oryzae) infects Arabidopsis via a mechanism distinct from that required for the infection of rice. Plant Physiol. 149: 474-486.

Pataky, J. K., and Chandler, M. A. 2003. Production of huitlacoche, Ustilago maydis: Timing inoculation and controlling pollination. Mycologia 95: 1261-1270.

Perez-Martin, J., Castillo-Lluva, S., Sgarlata, C., Flor-Parra, I., Mielnichuk, N., Torreblanca, J., and Carbo, N. 2006. Pathocycles: Ustilago maydis as 
a model to study the relationships between cell cycle and virulence in pathogenic fungi. Mol. Genet. Genomics 276:211-229.

Pohlmann, T., Baumann, S., Haag, C., Albrecht, M., and Feldbrügge, M 2015. A FYVE zinc finger domain protein specifically links mRNA transport to endosome trafficking. eLife 4:e06041.

Provart, N. J., Alonso, J., Assmann, S. M., Bergmann, D., Brady, S. M., Brkljacic, J., Browse, J., Chapple, C., Colot, V., Cutler, S., Dangl, J., Ehrhardt, D., Friesner, J. D., Frommer, W. B., Grotewold, E. Meyerowitz, E., Nemhauser, J., Nordborg, M., Pikaard, C., Shanklin, J., Somerville, C., Stitt, M., Torii, K. U., Waese, J., Wagner, D., and McCourt, P. 2016. 50 years of Arabidopsis research: Highlights and future directions. New Phytol. 209:921-944.

Rabe, F., Bosch, J., Stirnberg, A., Guse, T., Bauer, L., Seitner, D., Rabanal, F. A., Czedik-Eysenberg, A., Uhse, S., Bindics, J., Genenncher, B., Navarrete, F., Kellner, R., Ekker, H., Kumlehn, J., Vogel, J. P., Gordon, S. P., Marcel, T. C., Munsterkotters, M., Walter, M. C., Sieber, C. M. K., Mannhaupt, G., Guldener, U., Kahmann, R., and Djamei, A. 2016. A complete toolset for the study of Ustilago bromivora and Brachypodium sp. as a fungal-temperate grass pathosystem. eLife 5:e20522.

Roos, J., Bejai, S., Mozuraitis, R., and Dixelius, C. 2015. Susceptibility to Verticillium longisporum is linked to monoterpene production by TPS23/27 in Arabidopsis. Plant J. 81:572-585.

Sabbagh, S. K., Diagne-Lèye, G., Naudan, M., and Roux, C. P. 2010. Solopathogenic strain formation strongly differs among Ustilaginaceae species. FEMS Microbiol. Lett. 305:121-127.

Schirawski, J., Heinze, B., Wagenknecht, M., and Kahmann, R. 2005. Mating type loci of Sporisorium reilianum: Novel pattern with three $a$ and multiple $b$ specificities. Eukaryot. Cell 4:1317-1327.

Schulz, B., and Boyle, C. 2005. The endophytic continuum. Mycol. Res. 109:661-686.

Spellig, T., Bölker, M., Lottspeich, F., Frank, R. W., and Kahmann, R. 1994. Pheromones trigger filamentous growth in Ustilago Maydis. EMBO J. 13:1620-1627.

Szabo, Z., Tonnis, M., Kessler, H., and Feldbrugge, M. 2002. Structurefunction analysis of lipopeptide pheromones from the plant pathogen Ustilago maydis. Mol. Genet. Genomics 268:362-370.

Terrell, E. E., and Batra, L. R. 1982. Zizania latifolia and Ustilago esculenta, a grass-fungus association. Econ. Bot. 36:274-285.

Thomma, B. P. H. J., Eggermont, K., Tierens, K. F. M. J., and Broekaert, W. F. 1999. Requirement of functional ethylene-insensitive 2 gene for efficient resistance of Arabidopsis to infection by Botrytis cinerea. Plant Physiol. 121:1093-1101.

Turrà, D., El Ghalid, M., Rossi, F., and Di Pietro, A. 2015. Fungal pathogen uses sex pheromone receptor for chemotropic sensing of host plant signals. Nature 527:521-524.

Urban, M., Daniels, S., Mott, E., and Hammond-Kosack, K. 2002. Arabidopsis is susceptible to the cereal ear blight fungal pathogens Fusarium graminearum and Fusarium culmorum. Plant J. 32: 961-973.

Vánky, K. 1994. European Smut Fungi. Gustav Fischer Verlag, Stuttgart, Germany.

Vánky, K. 1999. The new classificatory system for smut fungi, and two new genera. Mycotaxon 70:35-49.

Vánky, K., and Lutz, M. 2007. Revision of some Thecaphora species (Ustilaginomycotina) on Caryophyllaceae. Mycol. Res. 111:1207-1219.

Vánky, K., Lutz, M., and Bauer, R. 2008. About the genus Thecaphora (Glomosporiaceae) and its new synonyms. Mycol. Prog. 7:31-39.

Vánky, K. 2012. Smut Fungi of the World. APS Press, St. Paul, MN, U.S.A.

Vasighzadeh, A., Zafari, D., Selcuk, F., Huseyin, E., Kursat, M., Lutz, M., and Piatek, M. 2014. Discovery of Thecaphora schwarzmaniana on Rheum ribes in Iran and Turkey: Implications for the diversity and phylogeny of leaf smuts on rhubarbs. Mycol. Prog. 13:881-892.

Vollmeister, E., Schipper, K., Baumann, S., Haag, C., Pohlmann, T., Stock, J., and Feldbrügge, M. 2012. Fungal development of the plant pathogen Ustilago maydis. FEMS Microbiol. Rev. 36:59-77.

Wei, F., Coe, E., Nelson, W., Bharti, A. K., Engler, F., Butler, E., Kim, H., Goicoechea, J. L., Chen, M., Lee, S., Fuks, G., Sanchez-Villeda, H., Schroeder, S., Fang, Z., McMullen, M., Davis, G., Bowers, J. E., Paterson, A. H., Schaeffer, M., Gardiner, J., Cone, K., Messing, J., Soderlund, C., and Wing, R. A. 2007. Physical and genetic structure of the maize genome reflects its complex evolutionary history. PLoS Genet. 3:e123.

Yu, J. J., Zhang, Y. F., Cui, H. F., Hu, P., Yu, X. P., and Ye, Z. H. 2015. An efficient genetic manipulation protocol for Ustilago esculenta. FEMS Microbiol. Lett. 362:fnv087.

\section{AUTHOR-RECOMMENDED INTERNET RESOURCE}

IndexMundi website: http://www.indexmundi.com 